\title{
'n Heuristiese model van vier tipes transendensie
}

Book Title:

Culture and Transcendence.

A Typology of Transcendence

Book Cover:

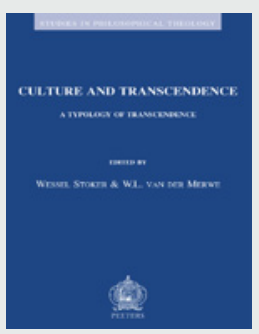

Editors:

W. Stoker

W.L. van der Merwe

ISBN:

978-90-429-2634-9

Publisher:

Peeters (Leuven 2012)

\section{$\square$}

Review Title:

'n Heuristiese model van vier

tipes transendensie

Reviewer:

Anné H. Verhoef ${ }^{1}$

Affiliation:

${ }^{1}$ School of Philosophy,

North-West University,

Potchefstroom, South Africa

Email:

anne.verhoef@nwu.ac.za

Postal address:

Private Bag X6001,

Potchefstroom 2520,

South Africa

How to cite this book

review:

Verhoef, A.H., 2012, "n

Heuristiese model van

vier tipes transendensie',

Koers - Bulletin for Christian

Scholarship 77(2), Art. \#437,

2 pages. http://dx.doi.org/

10.4102/koers.v77i2.437

(C) 2012. The Authors.

Licensee: AOSIS

OpenJournals. This work

is licensed under the

Creative Commons

Attribution License.
Hierdie boek is deel 50 van die reeks: Studies In Philosophical Theology. Die uitgangspunt daarvan is dus filosofies-teologies van aard en hierdie spesifieke werk fokus op die verhouding tussen transendensie en kultuur. Transendensie word deur Stoker en Van der Merwe gedefinieer as 'God, die absolute, Misterie, die Ander, die ander as ander of as alteriteit, afhangende van mens se wêreldbeskouing'. Die boek begin met 'n tipologie van transendensie wat aangebied word as 'n analitiese en heuristiese stuk gereedskap waarmee transendensie in ons hedendaagse kultuur ondersoek kan word. Die tipologie word nie voorgehou as finaal of voltooid nie, maar die waarde daarvan word gou duidelik in die bespreking van verskeie teoloë en filosowe se werke. Stoker onderskei vier tipes transendensie en die toepassing daarvan word gedoen deur verskillende skrywers, bekende teoloë en filosowe se werke te ondersoek.

By transendensie as (1) immanente transendensie (God of die absolute is direk met die mens verbind) word die teologie van Paul Tillich en Dietrich Bonhoeffer bespreek. Tillich se verstaan van transendensie het te make met die diepste gronde [ultimate concern] van alle wesens se bestaan. Bonhoeffer identifiseer ook transendensie met die goddelike, maar hy het 'n baie sterker Christologiese verstaan daarvan en hy is uitgesproke oor 'n transendensie wat hierdie wêreld daarvan los wil maak.

Onder (2) radikale transendensie (God of die absolute is die totaal andere en skerp onderskeibaar van die alledaagse realiteit) word Karl Barth en Marcel Gauchet se sieninge van transendensie bespreek. Barth identifiseer transendensie met die goddelike, maar verwerp enige idee van transendensie wat suggereer dat God op een of ander wyse immanent in hierdie wêreld is. Gauchet identifiseer ook transendensie met die goddelike, maar sien dit as iets negatiefs, as iets wat'n beperkende houvas op die mens het. Hoe meer transendent hierdie goddelike egter beskou word, hoe verder verwyderd is hy of sy van die mens en hoe swakker is hierdie houvas op die mens en hoe meer ruimte kom daar vir menslike outonomie.

Die (3) radikale immanensie (God of die absolute word nie meer buite die alledaagse gesoek nie) word beskou as die algemene rigting waarin postmodernistiese denke rakende transendensie beweeg. Van der Merwe beskryf dit as die verstek posisie in hedendaagse kultuur - in filosofie, politiek, kuns, selfs teologie. Goeie voorbeelde hiervan vind 'n mens in Gilles Deleuze se filosofie, sowel as in die kultus van ekstreme ervaringe in ons kontemporêre kultuur, soos wat Amanda du Preez dit beskryf.

As voorbeelde van hoe (4) transendensie as andersheid of alteriteit (verhouding tussen transendensie en immanensie is nie meer opponerend nie) verstaan kan word, word Luce Irigaray se filosofie, en trauma as transendensie bespreek. Die skeiding tussen transendensie en immanensie is vir Irigaray problematies en moet oorkom word, of dit moet anders bedink word sodat daar eties, en meer vervuld gelewe kan word en sodat daar werklike 'wording' kan plaasvind. In sy ondersoek na die verband tussen trauma en transendensie skryf Wytske Versteeg dat ervaring van trauma met transendensie te make het, want trauma het gewoonlik te make met gebeure wat onbeskryfbaar is, iets wat ons skok, iets onbegrypliks.

In kontras met Stoker se vier tipes transendensie, tref Merold Westphal net onderskeid tussen transendensie en immanensie. Hy groepeer transendensie as andersheid [alterity] onder transendensie, want by Derrida, sê hy, vind mens nie 'n dekonstruksie tussen transendensie en immanensie nie, maar ' $n$ herplasing daarvan.

Paul van Tongeren, in sy bespreking van nihilisme en transendensie, wys op die belang van transendensie om oriëntasie, waarde en interpretasie aan die wêreld te bied. God, as transendente, het lank hierdie rol vervul, maar met 'God se dood' is daar nou geen oriëntasiepunt oor nie en 
die mens bevind haar in 'n leë, betekenislose heelal, en net die niks (nihil) bly oor.

Arnold Burms sluit by Van Tongeren aan oor die eksistensiële noodsaak van nie-nihilistiese transendensie in sy bespreking van transendensie en chaos. Soortgelyk aan Van Tongeren beskryf hy die mens se behoefte aan transendensie as die behoefte om 'n konneksie te maak tussen iets wat vir ons spesifiek betekenisvol is en ' $n$ element in 'n eksterne of niemenslike realiteit, soos die natuur. Die probleem is egter dat die natuur onverskillig teenoor ons persoonlike dramas staan en dit ontlok 'n gevoel van verbystering, 'n chaotiese soort transendensie.

In geheel bied die boek 'n waardevolle bydrae tot die ondersoek na transendensie. Myns insiens slaag Stoker se tipologie om die gesprek oor transendensie meer genuanseerd te maak en in die besprekings blyk die waarde daarvan in terme van kultuurfilosofie en kultuurkritiek reeds duidelik. Die boek is gemik op 'n akademiese gehoor, maar enige iemand wat wil verder nadink oor transendensie sal dit toeganklik vind. 